\title{
Physical Characteristics and the Effect of Boiling and Fermentation on the Nutritional Value of Telfairia occidentalis Seeds
}

\author{
Mercy Bih Loh Achu*, Ruth Viviane Djuikwo, Stéphane Ghomsi Tamo, \\ Christiane Laure Maptouom Fotso, Michelle Carole Djouhou Fowe, Elie Fokou
}

Laboratory for Food Science and Metabolism, Department of Biochemistry, Faculty of Science, University of Yaoundé I, Yaoundé, Cameroon

Email: *mercyabih@gmail.com

How to cite this paper: Achu, M.B.L., Djuikwo, R.V., Tamo, S.G., Fotso, C.L.M., Fowe, M.C.D. and Fokou, E. (2021) Physical Characteristics and the Effect of Boiling and Fermentation on the Nutritional Value of Telfairia occidentalis Seeds. Journal of Agricultural Chemistry and Environment, 10, 389-401.

https://doi.org/10.4236/jacen.2021.104025

Received: July 8, 2021

Accepted: September 15, 2021

Published: September 18, 2021

Copyright $\odot 2021$ by author(s) and Scientific Research Publishing Inc. This work is licensed under the Creative Commons Attribution International License (CC BY 4.0).

http://creativecommons.org/licenses/by/4.0/

\begin{abstract}
This work evaluates some physical parameters (the weight, length, diameter of fruits and seeds, number of seeds per fruit) and the effect of boiling and fermentation on the nutritional value of Telfairia occidentalis (fluted pumpkin) seeds. Firstly, a survey was done in the city of Yaounde on the different treatments applied to the seeds before cooking. From the results of the survey, the seeds were divided into three groups: raw, boiled and fermented. The moisture, lipid, protein, fibre, carbohydrate and ash contents were analysed using AOAC methods and minerals by atomic absorption spectrophotometry. The results showed that $T$. occidentalis fruit averagely weighed $6.35 \mathrm{~kg}$ and contained about 90 seeds. The decorticated seeds had an ovoid shape, $3.70 \mathrm{~cm}$ long and weighed $8.91 \mathrm{~g}$. Boiling led to an increase in lipid $(16.29 \%-$ $31.44 \%)$ and carbohydrate $(19.20 \%-21.8 \%)$ but a decrease in protein $(54.06 \%$ $34.17 \%)$ contents. Fermentation increased the crude fibre $(0.70 \%-1.1 \%)$ but decreased the ash content $(4.07 \%-3.14 \% \mathrm{DM})$. Boiled seeds had higher calcium, magnesium, potassium and sodium, while fermented seeds had higher zinc levels. Boiling proved better in preserving most of the seed nutrients. These seeds could be used to prevent some mineral deficiencies and their high proteins suggest their potential for the formulation of infant foods.
\end{abstract}

\section{Keywords}

Physical Parameters, Nutritional Composition, Boiling, Fermentation, Telfairia occidentalis Seeds

\section{Introduction}

Telfairia occidentalis, also known as the fluted pumpkin, courge cannelée (in 
French), okonghobong (in Cameroon), is a vegetable of the Cucurbitaceae family, mostly found in the subtropical region of Africa. It grows in Central and West African areas. It is frequently found in Benin, Nigeria and Cameroon. In Nigeria and Benin, it is highly appreciated and is mainly used for its leaves and seeds. The tender shoots, succulent leaves and immature seeds are cooked and eaten as a vegetable. The leaves are $3-5$ and palmately arranged. The fruit is pale green, with waxy deposits, up to $25 \mathrm{~cm}$ in diameter and $3-6 \mathrm{~kg}$ in weight and with light yellow fibrous flesh. The seeds are flattened, about $3.5 \mathrm{~cm}$ in diameter and each fruit produces about 30 - 70 seeds. The harvesting of female shoots and leaves can begin 70 - 90 days after sowing, and the ripe fruit about 120 - 150 days after sowing.

The leaves of $T$. occidentalis are rich in proteins (29\%), lipids (18\%), minerals and vitamins (20\%) [1]. The leaves are very rich in $\mathrm{Mg}$, Fe and fibre [2]. Given their richness in minerals ( $\mathrm{P}, \mathrm{K}, \mathrm{Mg}, \mathrm{Ca}, \mathrm{Fe}$ ), vitamins ( $\mathrm{A}, \mathrm{B}$ and $\mathrm{C}$ ), fibre and antioxidants, these leaves are used to treat and/or relieve several diseases such as anaemia, typhoid, malaria, sickle cell disease [3] [4]. They are therefore of great nutritional, medicinal and industrial importance.

Concerning the seeds, a study conducted in Ivory Coast showed that the seeds contain about $50 \%$ lipids, $27 \%$ carbohydrates and $14 \%$ protein. They have a nutritional and calorific value, which could be used to establish diets as a source of proteins, minerals and also for the extraction of edible oils, for the oils contain mostly unsaturated fatty acids. They can be eaten roasted or boiled [5] [6]. They serve as raw materials for local industries for animal feed and chemical oils [7]. With the increasing use of fluted pumpkins, unlike in Nigeria where the plant is grown on an industrial scale and all plant parts such as vines, leaves and seeds are heavily used, the production and consumption of fluted pumpkin seeds in Cameroon is still very low and is limited to a few regions where mostly the leaves are consumed. This is partly due to the lack of knowledge on the nutritional and health value of these seeds and their slightly bitter taste. This work is aimed at describing the physical characteristics of the fluted pumpkin fruit and seeds from Cameroon and the effect of fermentation and boiling on the nutritional value of these seeds.

\section{Materials and Methods}

\subsection{Biological Materials}

The mature fruits (03) of Telfairia occidentalis were collected from a farmer in the city of Yaoundé and then identified at the National Herbarium, by comparison with the material of Westphal 9646 using the specimen Collection No. 42502 HNC (YA). These fruits were then transported to the Laboratory of Food Science and Metabolism (LabSAM) where they were split with a knife to extract the seeds. The weight of the whole fruit, the fibres and the empty fruit were determined by weighing using a scale. The weights of the unshelled, shelled, fresh and dried seeds were determined using a precision balance (Amsua brand, CAP. $3 \mathrm{Kg}$ GRAD. $25 \mathrm{~g}$ ). The dimensions (length, width, diameter) of the fruit as well as those of the seeds were measured using a graduated ruler. 
The seeds obtained were cleaned, shelled and divided into (03) three batches. The first batch was dried in a air ventilated oven at $50^{\circ} \mathrm{C}$ for 72 hours and ground (these were the raw seeds). The second batch was dried at $50^{\circ} \mathrm{C}$ for $72 \mathrm{~h}$, ground and the powder obtained was boiled in water at $100^{\circ} \mathrm{C}$ for $1 \mathrm{~h}$ (these were the boiled seeds). The last batch was soaked in warm water $\left(40^{\circ} \mathrm{C}\right)$ for 96 hours, dried at $50^{\circ} \mathrm{C}$ for 72 hours and ground (these were the fermented seeds).

\subsection{Methods of Analysis}

The moisture, ash, protein and carbohydrate contents were determined by the method described by A.O.A.C [8]. The lipid content was done by extraction according to the Russian method described by Bourely [9]. The crude fibre content was determined by successive digestion of $T$. occidentalis seeds powder with strong acid and base as described by A.O.A.C [10].

The energy value (EV) per $100 \mathrm{~g}$ of cotyledons was obtained using the Atwater conversion factors [11] as follows:

$$
\text { EV }(\text { Kcal })=\text { Proteins }(\%) \times 4+\text { Carbohydrate }(\%) \times 4+\text { Lipids }(\%) \times 9
$$

The determination of mineral content $(\mathrm{Cu}, \mathrm{Mg}, \mathrm{Fe}, \mathrm{Na}, \mathrm{Zn}, \mathrm{Ca}, \mathrm{K}, \mathrm{Mn})$, was done as described by Horwitz [12].

\section{Results and Discussion}

\subsection{Physical Characteristics of the Fruit}

Table 1 and Table 2 show some physical parameters of the fruit and seeds of Telfairia occidentalis. The whole fruit of Telfairia occidentalis is $45-50 \mathrm{~cm}$ long, $21-23 \mathrm{~cm}$ in diameter and weighs $4.7-8 \mathrm{~kg}$. The number of seeds produced per fruit varies according to the size of the fruit and can attend 80 to 100 seeds. A seed (without shell) is $3.39-4 \mathrm{~cm}$ wide and, $3.39-4 \mathrm{~cm}$ long. These results are similar to those of previous studies on this plant, which showed that the whole fruit had a diameter of $25 \mathrm{~cm}$, a weight of $3-6 \mathrm{~kg}$, contained $30-70$ seeds and a diameter of $3.5 \mathrm{~cm}$ for the seeds [1]. In addition to the seeds, the fruit contains orange fibres that can be used for animal feed. The weight of 100 shelled T. occidentalis seeds is much higher than those of other seeds of the same family Cucurbitaceae, such as C. maxima, where 100 shelled seeds weigh 7 - $16.5 \mathrm{~g}$ [13].

\subsection{Macronutrients}

Table 3 shows the water, lipid, protein, carbohydrate, crude fibre, ash contents and the energy value of Telfairia occidentalis seeds according to the different treatments. The water content is expressed in $\mathrm{g} / 100 \mathrm{~g}$ fresh weight (FW) and the other nutrients in $\mathrm{g} / 100 \mathrm{~g}$ dry weight (DW).

\subsubsection{The Moisture Content}

The moisture content of the Telfairia occidentalis seeds is 5.68 (raw seeds), 7.93 (boiled seeds) and 6.28\% FW (fermented) seeds (Table 3). The value of 5.68\% (raw seeds) is closed to $5.00 \%$ obtained for Cucurbita pepo L. seeds from Cameroon [5]. It can be seen that boiling with water and fermentation slightly in- 
creases the water content. This increase can be explained by the fact that during these treatments, the cells absorb water. On the other hand, a decrease in water content was observed after fermentation and boiling of Telfairia occidentalis seeds, with values ranging from $5.75 \%$ (raw seeds) to $1.40 \%$ (fermented seeds) and $4.59 \%$ (boiled seeds) [14]. However, the water contents of the seeds in this study remain favourable for better storage of the seeds.

Table 1. Physical parameters of the fruit of Telfairia occidentalis.

\begin{tabular}{ccc}
\hline Parameter & Values & Percentage (\%) \\
\hline Weight of the whole fruit $(\mathrm{kg})$ & $4.70-8(6.35 \pm 0.5)$ & 100 \\
Weight of fibres $(\mathrm{kg})$ & $1.09-1.5(1.29 \pm 0.4)$ & 20.31 \\
Weight of the empty fruit $(\mathrm{kg})$ & $2.5-3.5(3 \pm 0.2)$ & 47.24 \\
Length of fruit $(\mathrm{cm})$ & $45-50(47.5 \pm 0.3)$ & $/$ \\
Width of fruit $(\mathrm{cm})$ & $21.5-23(22.25 \pm 0.1)$ & $/$ \\
Diameter of fruit $(\mathrm{cm})$ & $21-23(22 \pm 0.1)$ & $/$ \\
Total number of seeds & $80-100(90 \pm 5)$ & $/$ \\
\hline
\end{tabular}

Table 2. Physical parameters of the seeds of Telfairia occidentalis.

\begin{tabular}{cc}
\hline Parameter & Values \\
\hline Weight of a whole seed (with shelled) $(\mathrm{g})$ & $12.93-14.02(13.48 \pm 0.3)$ \\
Weight of seed (without shell) $(\mathrm{g})$ & $8.79-9.02(8.91 \pm 0.3)$ \\
Weight of shells $(\mathrm{g})$ & $4.05-5(4.03 \pm 0.2)$ \\
Length of a seed (with shell) $(\mathrm{cm})$ & $3.78-4.3(4.04 \pm 0.5)$ \\
Length of a seed (without shell) $(\mathrm{cm})$ & $3.39-4(3.70 \pm 0.2)$ \\
Width of a seed (with shell) $(\mathrm{cm})$ & $3.66-4.1(3.81 \pm 0.4)$ \\
Width of a seed (without shell) $(\mathrm{cm})$ & $3.39-4(4.00 \pm 0.2)$ \\
Shape of Seed & Ovoid
\end{tabular}

Table 3. Macronutrient content and energy value of raw, boiled and fermented Telfairia occidentalis seeds.

\begin{tabular}{|c|c|c|c|}
\hline Parameter (\%) & Raw Seeds & Boiled Seeds & Fermented Seeds \\
\hline Water content (FW) & $5.68 \pm 0.12^{\mathrm{a}}$ & $7.93 \pm 0.23^{b}$ & $6.28 \pm 0.09^{\mathrm{a}}$ \\
\hline Lipids & $16.29 \pm 0.29^{\mathrm{a}}$ & $31.44 \pm 1.38^{\mathrm{b}}$ & $19.03 \pm 0.92^{\mathrm{a}}$ \\
\hline Proteins & $54.06 \pm 1.20^{\mathrm{b}}$ & $34.17 \pm 0.88^{\mathrm{a}}$ & $54.36 \pm 1.55^{\mathrm{b}}$ \\
\hline Carbohydrates & $19.20 \pm 1.00^{\mathrm{b}}$ & $21.80 \pm 1.00^{c}$ & $16.09 \pm 1.00^{\mathrm{a}}$ \\
\hline Crude fibres & $0.70 \pm 0.31^{\mathrm{a}}$ & $0.62 \pm 0.08^{\mathrm{a}}$ & $1.1 \pm 0.57^{\mathrm{a}}$ \\
\hline Ash & $4.07 \pm 0.14^{\mathrm{b}}$ & $4.06 \pm 0.12^{\mathrm{b}}$ & $3.14 \pm 0.27^{\mathrm{a}}$ \\
\hline Energy (Kcal) & 439.65 & 506.68 & 453.07 \\
\hline
\end{tabular}

Values with different letter superscripts within the same row are significantly different ( $\mathrm{p}$ $<0.05)$. 


\subsubsection{The Lipid Content}

The lipid content of Telfairia occidentalis seeds is 16.29 (raw), 31.44 (boiled) and $19.03 \%$ DW (fermented) seeds (Table 3). Boiling with water resulted in a significant increase while fermentation caused an insignificant increase in the lipid content of the seeds. As observed in these seeds, an increase in lipid content after fermentation of the cotyledons of melon (Citrullus vulgaris) and African locust (Parkia biglobosa) had been obtained [15] [16]. The low activity of lipases could explain this slight increase. Low lipase activity during fermentation is important for improving organoleptic quality and reducing rancidity [17]. The significant increase in lipid content in boiled seeds $(31.44 \pm 1.38 \mathrm{~g} / 100 \mathrm{~g})$, can be explained by the fact that during boiling, the cells burst and membrane lipids are liberated, hence making lipids available. A decrease in lipid content after boiling and an increase after fermentation of Telfairia occidentalis seeds from Nigeria was obtained (from $50.49 \%$ to $42.74 \%$ and $56.91 \%$ respectively) [14]. For a balanced diet, lipids should cover $30 \%-35 \%$ of the total energy intake [18]. Our boiled seeds cover $56 \%$ and fermented seeds $38 \%$ of the total energy intake. They are therefore rich in lipids and could be used to cover the energy needs from lipids. They can also be used for the extraction of edible oils.

\subsubsection{The Protein Content}

The protein content of the seeds is $54.06 \mathrm{~g}$ for raw, $34.17 \mathrm{~g}$ for boiled and $54.36 \%$ DW for fermented seeds (Table 3). A significant difference $(\mathrm{P}<0.05)$ is observed between the protein contents of the raw and boiled seeds. The boiled seeds have the lowest protein content $(34.17 \mathrm{~g} / 100 \mathrm{~g})$ compared to the raw and fermented seeds. This may be due to the denaturation of proteins during boiling [19]. During fermentation there was no significant difference in the protein contents $(54.36 \mathrm{~g} / 100 \mathrm{~g})$ of the raw and fermented seeds, which remained high in the fermented samples. Other studies have also reported insignificant variation in protein content of Cucurbit seeds after fermentation. For example, the protein contents did not vary significantly after $72 \mathrm{~h}$ of fermentation of the cotyledons of Citrullus vulgaris, Cucumeropsis sativus and Citrullus colocynthis [20]. On the other hand, an increase in the protein content of soybeans after fermentation had been observed [21]. This could be explained by the fact that during fermentation, the medium was rich in other substances (such as nitrogen) degradable by the microorganisms present in the medium, which may increase the biomass of the fermentation medium. The values obtained in this work (54.06 for raw, 34.17 for boiled and 54.36 for fermented seeds) are higher than 30.42 (raw), 29.92 (boiled) and 35.06 (fermented seeds) obtained for Telfairia occidentalis seeds from Nigeria [14]. This difference may be due to different growth factors (climate, soil), the place of seed collection, the state of maturity of the seeds and the conditions of storage of these seeds [22]. The protein content of the raw and fermented seeds of T. occidentalis (54\%) is higher than those of other Cucurbitaceae seeds such as C. mannii (40.49), C. maxima (34.93) and L. siceraria (34.19)\% DW [23]. These fermented seeds can be a good source of protein for the formu- 
lation of infant foods.

\subsubsection{The Carbohydrate Content}

The total carbohydrate content of Telfairia occidentalis seeds is 19.20 (raw), 21.80 (boiled) and $16.09 \%$ DW for (fermented) seeds (Table 3). These results are significantly $(\mathrm{P}<0.05)$ different from each other. A decrease in carbohydrate content was observed in the fermented seeds. Similar results were obtained on the same seeds from Nigeria [14]. A significant decrease in sugars during the fermentation of melon cotyledons (Citrullus vulgaris) and the African locust bean (Parkia biglobosa) was also obtained [15]. This decrease in total carbohydrates is thought to be due to the activity of the microorganisms that use these sugars for energy. The values obtained in this study are higher than $11.41 \%$ (raw) and $3.62 \%$ (fermented) but similar to $22.30 \%$ for boiled $T$. occidentalis seeds from Nigeria [14]. On the other hand, the carbohydrate content of the raw seeds in this study (19.20\%) is lower than $26.76 \%$ obtained for these raw seeds from $\mathrm{Ni}$ geria [6]. This low carbohydrate content in fermented seeds makes these seeds a potential source of meal for people with diabetes.

\subsubsection{The Crude Fibre Content}

The Telfairia occidentalis seeds analysed had an average crude fibre content of $0.70 \%, 0.62 \%$ and $1.1 \%$ DW for raw, boiled and fermented seeds respectively (Table 3). There was no significant difference between these values $(P>0.05)$. The crude fibre content of the raw seeds (0.70) is similar to that of these seeds from Nigeria (1.00\% DM) [5]. Boiling and fermentation of these seeds had no significant effect on the crude fibre content. However, the slightly higher value in the fermented seeds, could be explained by the fact that during fermentation the hydrolysis of compounds such as carbohydrates partly releases fibres. An increase in crude fibre content during fermentation of B. Eurycoma seeds was observed and this was attributed to the metabolic activity of microorganisms involved in fermentation. Microorganisms are able to transform the substrate molecules in which they are found into assimilable molecules. Among these substrate molecules are peptidoglycan and cellulose, found in the membranes of bacterial and plant cells respectively [24]. The increase in fibre content in these fermented cotyledons is very important for health, for the consumption of fibre-rich foods is associated with a reduced risk of developing heart disease, colon and rectal cancer, diabetes, constipation and appendicitis [25].

\subsubsection{The Ash Content}

The ash content of these Telfairia occidentalis seeds is 4.07, 4.06 and 3.14 for raw, boiled and fermented seeds respectively (Table 3 ). The ash content of the raw seeds (4.07) is less than $5.08 \%$ obtained for raw $T$. occidentalis seeds from Nigeria [14]. After boiling, there was no significant difference in the ash content of the raw and boiled samples. There was a reduction in the ash content in the fermented seeds, these authors also observed a reduction in the ash content of these seeds after fermentation and cooking of Telfairia occidentalis seeds. On the 
other hand, an increase was observed during fermentation of Jatropha curcas seeds [26], which could be attributed to the contribution of microorganisms involved in fermentation, that degrade anti-nutritional factors, thus releasing complexed minerals [27]. However, these boiled and fermented seeds have a significant amount of minerals that can be used to combat some mineral deficiencies.

\subsection{The Energy Value}

The energy value of a food compound is the some of the products of each major food (carbohydrates, proteins, lipids) and its thermal coefficient of corresponding Atwater [11]. The boiled seeds had the highest energy value (506.68), followed by the fermented seeds (453.07) and raw seeds (439.65) (Table 3). Boiling lead to a significant increase in the lipid and carhohydrates contents, which greatly increased the energy value of the boiled seeds.

\subsection{Minerals}

The mineral content of Telfairia occidentalis seeds according to the different treatments, expressed in $\mathrm{mg} / 100 \mathrm{~g}$ dry weight (DW), is shown in Table 4.

\subsubsection{Calcium (Ca)}

The calcium content is 43.5 (raw), $48 \mathrm{mg}$ (boiled) and $30.5 \mathrm{mg} / 100 \mathrm{~g}$ DW (fermented) seeds (Table 4). These results are not significantly $(\mathrm{P}<0.05)$ different from each other. There is an insignificant decrease in the calcium content after fermentation. This decrease could be explained by the fact that during fermentation there is calcium leaching. The increase observed after boiling could be due to the fact that during boiling there was a release of calcium which had been complexed by phytate. An increase in calcium content after boiling and fermentation was obtained for these seeds from Nigeria with values of 77. $99 \mathrm{mg}$ (raw),

Table 4. Mineral content of raw, boiled and fermented seeds of Telfairia occidentalis.

\begin{tabular}{cccc}
\hline Mineral (mg/100g DW) & Raw Seeds & Boiled Seeds. & Fermented Seeds. \\
\hline Ca & $43.5 \pm 10.61^{\mathrm{a}}$ & $48 \pm 5.66^{\mathrm{a}}$ & $30.5 \pm 6.36^{\mathrm{a}}$ \\
$\mathbf{M g}$ & $509 \pm 9.90^{\mathrm{b}}$ & $486 \pm 9.90^{\mathrm{b}}$ & $423 \pm 14.14^{\mathrm{a}}$ \\
$\mathbf{K}$ & $2525 \pm 91.92^{\mathrm{b}}$ & $2435.5 \pm 62.93^{\mathrm{b}}$ & $1937 \pm 32.53^{\mathrm{a}}$ \\
$\mathbf{N a}$ & $0.05 \pm 0.00^{\mathrm{a}}$ & $\mathbf{0 . 1 0 \pm 0 . 0 0 ^ { \mathrm { b } }}$ & $0.05 \pm 0.00^{\mathrm{a}}$ \\
$\mathbf{P}$ & $1364 \pm 118.79^{\mathrm{a}}$ & $1237 \pm 151.32^{\mathrm{a}}$ & $1234.5 \pm 147.78^{\mathrm{a}}$ \\
$\mathbf{M n}$ & $0.03 \pm 0.00^{\mathrm{b}}$ & $0.03 \pm 0.00^{\mathrm{b}}$ & $0.01 \pm 0.00^{\mathrm{a}}$ \\
$\mathbf{F e}$ & $0.08 \pm 0.00^{\mathrm{a}}$ & $0.10 \pm 0.01^{\mathrm{a}}$ & $0.09 \pm 0.02^{\mathrm{a}}$ \\
$\mathbf{Z n}$ & $0.05 \pm 0.00^{\mathrm{a}}$ & $0.05 \pm 0.00^{\mathrm{a}}$ & $0.06 \pm 0.00^{\mathrm{b}}$ \\
$\mathbf{C u}$ & $0.07 \pm 0.00^{\mathrm{b}}$ & $0.06 \pm 0.00^{\mathrm{a}}$ & $0.07 \pm 0.00^{\mathrm{b}}$ \\
\hline
\end{tabular}

Values with different letter superscripts within the same row are significantly different ( $\mathrm{p}$ $<0.05)$. 
$93.40 \mathrm{mg}$ (boiled) and $131.79 \mathrm{mg} / 100 \mathrm{~g}$ DM (fermented seeds) [14]. Calcium is known as a macroelement necessary for the development of teeth, bones and the release of hormones [28]. Daily calcium requirements are $700-1300 \mathrm{mg}$ for children and 1000 - $1300 \mathrm{mg}$ for adults [29]. These seeds should be prepared and consumed with calcium-rich foods for a good nutritional balance.

\subsubsection{Magnesium (Mg)}

The magnesium content of $T$. occidentalis seeds are 509 (raw), 486 (boiled) and $423 \mathrm{mg} / 100 \mathrm{~g}$ DW (fermented) seeds (Table 4). The magnesium content of the fermented seeds (423) is significantly lower than that of the raw and boiled seeds, which may be explained by the fact that during fermentation magnesium is used as a cofactor for certain enzymes. The values obtained are much higher than $1.90,1.11$ and $1.30 \mathrm{mg} / 100 \mathrm{~g}$ DW for raw, boiled and fermented T. occidentalis seeds from Nigeria respectively [14]. The magnesium values in this study are above the recommended daily magnesium requirements which range from $80-130 \mathrm{mg}$ for children and $240-420 \mathrm{mg}$ for adults [29]. Magnesium is a mineral necessary for enzymes using adenosine triphosphate which contributes to DNA and RNA synthesis during cell proliferation. Magnesium deficiency causes convulsions and irritability. T. occidentalis seeds can be considered as a source of magnesium and would help to solve these problems for, $100 \mathrm{~g}$ of these seeds can largely cover the recommended daily needs for $\mathrm{Mg}$ for all age groups.

\subsubsection{Potassium (K)}

The potassium content of $T$. occidentalis seeds is $2525 \mathrm{mg}$ (raw), $2435.5 \mathrm{mg}$ (boiled) and $1937 \mathrm{mg} / 100 \mathrm{~g}$ DM (fermented) seeds (Table 4). Boiling and fermentatiion resulted to a decrease in potassium content. This considerable decrease in potassium observed after seed fermentation could be explained by the fact that during fermentation potassium leaching occurred. A decrease in potassium content was also observed after fermentation of $T$. occidentalis seeds from Nigeria [14]. Potassium is an extracellular cation that is necessary for the functioning of the heart and plays an essential role in the contraction of skeletal and smooth muscles, making it important for digestive and muscle function. Potassium deficiency causes palpitation, abdominal restriction, nausea and constipation [30]. The values obtained after treatment of these seeds are higher than the range of RDA ( 800 to $1600 \mathrm{mg} / 100 \mathrm{~g}$ ) for children of 2 to 9 years old [31]. T. occidentalis seeds could be considered as a source of potassium.

\subsubsection{Sodium (Na)}

The sodium contents are 0.05 (raw), 0.10 (boiled) and $0.05 \mathrm{mg} / 100 \mathrm{~g}$ DW (fermented) seeds. There is a significant difference $(\mathrm{P}<0.05)$ between the value obtained after boiling and that obtained after fermentation. The highest content is that of boiled seeds, it could be due to the fact that during boiling the intracellular sodium is released under the effect of heat by destruction of the cell membrane. For the fermented seeds, the content remained unchanged. The sodium contents obtained for these seeds from Nigeria were much higher than the values 
obtained in this study and also showed no significant difference between the values of raw and fermented seeds (303.04 and $311.48 \mathrm{mg} / 100 \mathrm{~g}$ DM respectively), but were significantly higher from that of the boiled seeds $(275.48 \mathrm{mg} / 100 \mathrm{~g}$ DW) [14]. Excessive intake of sodium in foods promotes high blood pressure or the formation of oedema in some people. Sodium is necessary to maintain the osmotic balance of body fluids, control glucose absorption and improve normal protein retention during growth [32]. The $R D A$ for $\mathrm{Na}$ is between $1000-1500$ $\mathrm{mg} /$ day for children, men and women [29]. These seeds are low in sodium and high in potassium, which may have potential in the control of hypertension.

\subsubsection{Phosphorus (P)}

The phosphorus contents are 1364 (raw), 1237 (boiled) and $1234 \mathrm{mg} / 100 \mathrm{~g}$ DM (fermented) seeds (Table 4). Boiling and fermentation led to a decrease in the phosphorus content, but this difference is not significant $(\mathrm{P}>0.05)$. These results are much higher than $10.58 \mathrm{mg}$ (raw), $5.81 \mathrm{mg}$ (boiled) and $12.49 \mathrm{mg} / 100 \mathrm{~g}$ DW (fermented) seeds obtained for these seeds from Nigeria [14]. The phosphorus content of our seeds after treatment is closed to the daily phosphorus requirements of $100-1250 \mathrm{mg}$ for children and $700-1250 \mathrm{mg}$ for adults [29]. Phosphorus enables the fixation of calcium in the bones by decreasing its urinary excretion and takes part in the mechanism of energy storage and release [33]. These seeds of T. occidentalis can be considered as a source of phosphorus.

\subsubsection{Manganese (Mn)}

The manganese content of $T$. occidentalis seeds is $0.03 \mathrm{mg}$ (raw and boiled) and $0.01 \mathrm{mg} / 100 \mathrm{~g}$ DW (fermented) seeds (Table 4). The value for raw and boiled seeds is significantly $(\mathrm{P}<0.05)$ higher than that of fermented seeds. Fermentation reduced the content of $\mathrm{Mn}$ but boiling did not affect it. This could be due to the fact that fermentation might have led to the leaching of Mn. The same findings were observed after boiling and fermentation of these seeds from Nigeria, with values 21.96, 22.28, 8.44 for raw, boiled and fermented seeds respectively [14]. Manganese activates various enzymes which are important for proper digestion and utilization of food. The Adequate Dietary Intake for $\mathrm{Mn}$ are 1.2 (children), 1.8 - 2.3 (men and women) and $2 \mathrm{mg} /$ day (pregnant women) respectively [29]. These samples have low Mn levels, so they need to be supplemented with manganese-rich diets.

\subsubsection{Iron (Fe)}

The iron content of T. occidentalis seeds is 0.08 (raw), 0.10 (boiled) and 0.09 $\mathrm{mg} / 100 \mathrm{~g}$ DM (fermented) seeds (Table 4). Fermentation and boiling slightly increased the iron content of the seeds, but this increase is not significant $(\mathrm{P}>$ 0.05). Also, fermentation increased, while boiling decreased the iron content of these seeds from Nigeria [14]. Our values are lower than the RDA for iron (7 $16 \mathrm{mg} / 100 \mathrm{~g}$ ) [34]. These seeds therefore need to be eaten with iron-rich foods for a better nutritional balance. 


\subsubsection{Zinc (Zn)}

The zinc contents of $T$. occidentalis seeds are 0.05 (raw and boiled) and 0.06 $\mathrm{mg} / 100 \mathrm{~g}$ DM (fermented seeds). Fermentation slightly increased the zinc content of these seeds, while boiling did not affect it. This could be explained by the fact that during fermentation the anti-nutritional factors are hydrolysed releasing the zinc that was chelated by them. Zinc helps to strengthen the immune system which is important to speed up the healing process after cell damage. The $\mathrm{Zn}$ contents of our samples are lower than the RDA of 3 (children), 8 - 11 (men and women) and $11-12 \mathrm{mg} /$ day (pregnant women) [29]. These seeds should be consumed with zinc-rich foods for a better nutritional balance.

\subsubsection{Copper (Cu)}

The copper contents of T. occidentalis seeds are 0.07 (raw), 0.06 (boiled) and $0.07 \mathrm{mg} / 100 \mathrm{~g}$ DW (fermented) seeds (Table 4). Boiling slightly decreased the copper content, but no effect was observed with fermentation. The copper content of the raw and fermented seeds is $0.07 \mathrm{mg} / 100 \mathrm{~g}$ DW. This value is much lower than $40.60 \mathrm{mg} / 100 \mathrm{~g}$ DW obtained for these seeds from Nigeria [14]. Copper is found in trace amounts in these samples before and after treatment. The amount of copper in these seeds is lower than the $R D A$ for $\mathrm{Cu}$ which is 0.34 0.44 (children), 0.7 - 0.9 (men and women) and $1 \mathrm{mg} /$ day for (pregnant women) [29]. Meals prepared with these seeds should therefore be supplemented with copper-rich foods, in order to prevent copper deficiency.

On the whole, the mineral contents vary according to the treatment applied to the seeds during preparation.

\section{Conclusions}

This study which was aimed at determining the physical characteristics and the effect of boiling and fermentation on the nutritional value of Telfairia occidentalis seeds revealed that the fruit has an average weight of $6.35 \mathrm{~kg}$, it is about $47 \mathrm{~cm}$ long, $22 \mathrm{~cm}$ wide and contains an average of 90 seeds. The fresh seeds after removal of the shell have an ovoid shape, have an average weight of $8.91 \mathrm{~g}$ and are $3.39 \mathrm{~cm}$ long and wide.

T. occidentalis seeds have a good nutritional potential. They are rich in lipids, proteins and carbohydrates. The lipid content increases with boiling (48.19\%) and fermentation (14.4\%). The protein content decreases with boiling (58.20\%) but remains unchanged with fermentation while the carbohydrate content increases with boiling (11.92\%) but decreases with fermentation (19.33\%). The high protein levels in the fermented seeds make them have potential for the formulation of infant foods. These seeds also contain ash with a content that decreases with fermentation (29.62\%) and crude fibre whose content increases with fermentation (36.36\%). For minerals, these seeds are rich in $\mathrm{Mg}, \mathrm{K}$ and P. These mineral contents slightly decrease with boiling and fermentation, but remain high enough, as $100 \mathrm{~g}$ of these seeds can cover the recommended daily needs for $\mathrm{Mg}, \mathrm{K}$ and $\mathrm{P}$ in all age groups, thus could help to prevent these mineral deficien- 
cies. Further studies are envisaged on the digestibility and bioavailability of the macro and micronutrients in these seeds and on the extraction of $\mathrm{Mg}, \mathrm{K}$ and $\mathrm{P}$ supplements.

\section{Conflicts of Interest}

The authors declare no conflicts of interest regarding the publication of this paper.

\section{References}

[1] Akanbi, W.B., Adebooye, C.O., Togun, A.O., Ogunrinde, J.O. and Adeyeye, S.A. (2007) Growth, Herbage and Seed Yield and Quality of Telfairia occidentalis as Influenced by Cassava Peel Compost and Mineral Fertilizer. World Journal of Agricultural Sciences, 3, 508-516.

[2] Odiaka, N.I. and Schippers, R.R. (2004) Telfairia occidentalis Hook. f. Record from PROTA4U. Grubben, G.J.H. \& Denton, O.A. (Editors). PROTA (Plant Resources of Tropical Africa/Ressources végétales de l'Afrique tropicale), Wageningen, Netherlands. http://www.prota4u.org/search.asp

[3] Esseyin, O.A., Star, M.A., Rathore, H.A., Ahmad, A., Afzal, S., Lazhari, M., et al. (2014) Hypoglycemic Potential of Polysaccharides of the Leaf Extract of Telfairia occidentalis. Annual Research and Review in Biology, 4, 1813-1820. https://doi.org/10.9734/ARRB/2014/8476

[4] Patrick, T.M.C., Gann Hernandez, A.G. and Russell Ware, E. (2017) Sickle Cell Anemia in Sub-Saharan Africa: Advancing the Clinical Paradigm through Partnerships and Research. https://www.bloodjournal.org

[5] Elinge, C.M., Muhammad, A., Atiku, F.A., Itodo, A.U., Peni, I.J., Sanni, O.M., et al. (2012) Proximate, Mineral and Anti-Nutrient Composition of Pumpkin (Cucurbita pepo L.) Seeds Extract. International Journal of Plant Research, 2, 146-150. https://doi.org/10.5923/j.plant.20120205.02

[6] Koffi, N.B.C., Yapo, S.E.S. and Koffi, P.V.N. (2016) Evaluation of Some Biochemical and Agronomic Parameters of an Ivory Coast Forest Plant: Telfairia occidentalis Hook. F. International Journal of Agronomy and Agricultural Research, 9, 26-32.

[7] Christian (2007) A Fluted Pumpkin (Telfairia occidentalis Hook F.) Seed: A Nutritional Assessment. Electronic Journal of Environmental, Agricultural and Food Chemistry, 6, 1787-1793.

[8] AOAC Association of Official Analytical Chemists (1980) Official Methods of Analysis. 13th Edition, 102 p.

[9] Bourely, J. (1982) Observations sur le dosage de l'huile des graines de cotonnier. Coton et Fibres Tropicales, 27, 183-196.

[10] AOAC Association of Official Analytical Chemists (1990) Official Methods of Analysis. 15th Edition, $102 \mathrm{p}$.

[11] Merill, A.L. and Watt, B.K. (1955) Energy Value of Food Basis and Derivation. Handbook No. 74, US Department of Agriculture, Washington DC.

[12] Horwitz, W. (2000) Official Methods of Analysis of AOAC. 17th Edition, AOAC International, Rockville.

[13] Achu, M.B. (2006) A Study of Some Physicochemical Characteristics and Nutritional Properties of Five Cucurbitaceae Oil Seeds from Cameroon. PhD Thesis, University of Yaoundé 1, Yaoundé, $180 \mathrm{p}$. 
[14] Fagbemi, T.N., Oshodi, A.A. and Ipinmoroti, K.O. (2007) Processing Effects on Some Antinutritional Factors and in Vitro Multienzyme Protein Digestibility (IVPD) of Three Tropical Seeds: Breadnut (Artocarpus altilis), Cashewnut (Anacardium occidentale) and Fluted Pumpkin (Telfairia occidentalis). Pakistan Journal of nutrition, 4, 250-256. https://doi.org/10.3923/pjn.2005.250.256

[15] Omafuvbe, B.O., Olumuyiwa, S.E., Bolanle, A.O. and Steve, R.A. (2004) Chemical and Biochemical Changes in African Locust Bean (Parkia biglobosa) and Melon (Citrullus vulgaris) Seeds during Fermentation of Condiments. Pakistan Journal of Nutrition, 3, 140-145. https://doi.org/10.3923/pjn.2004.140.145

[16] Odebunmi, E.O., Oluwaniyi, O.O. and Bashiru, M.O. (2010) Comparative Proximate Analysis of Some Food Condiments. Journal of Applied Sciences and Research, 6, 272-274.

[17] Odunfa, S.A. (1983) Biochemical Changes during the Production of Ogiri, a Fermented Melon (Citrullus vulgaris Schrad) Product. Plant Foods for Human Nutrition, 32, 11-18. https://doi.org/10.1007/BF01093925

[18] ANSES (2016) Contribution of Macronutrients to Energy Intake. Collective Expertise Report, Referral No. 2012-SA-0186, 84 p.

[19] Djuikwo, N.R.V. (2014) Nutritional Potential of Leafy Vegetables in the SudanoGuinean Region of Cameroon. PhD Thesis, University of Ngaoundéré, Ngaoundéré, $111 \mathrm{p}$.

[20] Akinyele, B.J. and Oloruntoba, O.S. (2013) Comparative Studies on Citrullus vulgaris, Citrullus colocynthis and Cucumeropsis mannii for Ogiri Production. British Microbiology Research Journal, 3, 1-18. https://doi.org/10.9734/BMRJ/2013/2337

[21] Terlabie, N.N., Sakyi, D.E., Amoa, A. and Kofi, W. (2006) The Comparative Ability of Four Isolates of Bacillus subtilis to Ferment Soybeans into Dawadawa. International Journal of Food Microbiology, 106, 145-152. https://doi.org/10.1016/j.ijfoodmicro.2005.05.021

[22] Kajihausa, O.E., Sobukola, O.P., Idowu, M.A. and Awonorin, S.O. (2010) Nutrient Contents and Thermal Degradation of Vitamins in Organically Grown Fluted Pumpkin (Telfairia occidentalis) Leaves. International Food Research Journal, 17, 795-807.

[23] Achu, M.B., Fokou, E., Tchiégang, C., Fotso, M. and Mbiapo, T.F. (2005) Nutritive Value of Some Cucurbitaceae Oilseeds from Different Regions in Cameroon. African Journal of Biotechnology, 4, 1329-1334.

[24] Eze, S.O. and Ibe, O.J. (2005) Effect of Fermentation on the Nutritive Value of $B$. eurycoma "Achi". Journal of Chemistry Society of Niger, 30, 1.

[25] Lajide, L., Oseke, M.O. and Olaoye, O.O. (2008) Vitamin C, Fibre, Lignin and Mineral Contents of Some Edible Legume Seedlings. Journal of Food Technology, 6, 237-241.

[26] Oseni, O.A. and Akindahunsi, A.A. (2011) Some Phytochemical Properties and Effect of Fermentation on the Seed of Jatropha curcas L. American Journal of Food Technology, 6, 158-165. https://doi.org/10.3923/ajft.2011.158.165

[27] Oladele, P.E. and Oshodi, A.A. (2008) Effect of Fermentation on Some Chemical and Nutritive Properties of Berlandier Nettle Spurge (Jatropha curcas) Seeds. Pakistan Journal of Nutrition, 7, 292-296. https://doi.org/10.3923/pjn.2008.292.296

[28] Beto, J.A. (2015) The Role of Calcium in Human Ageing. Clinical Nutrition Research, 4, 1-8. https://doi.org/10.7762/cnr.2015.4.1.1

[29] FAO-WHO (2001) Human Vitamin and Mineral Requirements. Report of a Joint FAO/OMS Expert Consultation, Bangkok, 281 p. 
[30] Akpanyung, E.O. (2005) Proximate and Mineral Composition of Bouillon Cubes Produced in Nigeria. Pakistan Journal of Nutrition, 4, 327-329.

https://doi.org/10.3923/pjn.2005.327.329

[31] SCF (1993) Nutrient and Energy Intakes for the European Community. Reports of the Scientific Committee for Food, Thirty-First Series (SCF), European Commission, Luxembourg.

[32] NRC/NAS (1980) National Research Council Committee on Dietary Allowances. Recommended Dietary Allowances. 290-294.

[33] EFSA (European Food Safety Authority) (2014) Scientific Opinion on Dietary Reference Values for Zinc. EFSA Journal, 12, 3844.

https://doi.org/10.2903/j.efsa.2014.3844

[34] Grenoble, E.F. (2010) Besoins Nutritionnels, Reseau LINUT. 103 p. 